\title{
Teaching Reading Comprehension through Focal Points on R2D2 Model
}

\author{
Yudi Hari Rayanto \\ STKIP PGRI Pasuruan \\ e-mail: rayanto75@gmail.com
}

\begin{abstract}
This research is taken based on the teaching and learning which is conducted toward the new college students in 12 meetings. The teaching and learning itself is arranged based on the focal points which exist in R2D2 model, they are define, design and development, and dissemination The purposes of this research are to find out (1) college students' response during the learning process on Reading comprehension, and (2) college students' learning achievement during the learning process on Reading comprehension. The data are gained from questionnaires and test given to 31 college students in those meetings. From 12 meetings, there are two college students do not attend the learning process and automatically, the researcher only gets 29 questionnaires and answer sheets. All data are analyzed by using descriptive quantitative study. The result shows that college students' response is categorized high, that is 0,93 (93\%) and the result of college student's learning achievement can also be categorized high, all students get more than 90. Keywords: Teaching, Learning, Reading, R2D2, Focal points
\end{abstract}




\section{INTRODUCTION}

Teaching is a process interaction between lecturer and students college, Degeng (2013). This process is used to make students learn based on their own prior knowledge. This learning process involves three important components, they are its activity, lecturers, and college students. In its implementation, the lecturers often put themselves as the core of learning process. As the consequences, the learning process can be said less optimal, because the learning process is only informative. It happens because the learning process is not directed to the process of learning itself, which is constructing college students' prior knowledge, Ardhana (1997). As we know, college students are different into one another. They have their own unique. Recognizing from their uniqueness, the lecturer must pay attention on its different, so the learning process can really alter the condition of its process, from not (less) knowing to knowing, or does not understand into understand.

In learning, mostly, lecturers thought if they cannot attend and give the material in the classroom, the students are assumed that they do not master anything. This assumption can be true because in fact when students come to campus and the lecturers cannot attend, they mostly are lazy to do a scientific learning activity. Besides that, when the students college are in the classroom though the lecturer exists and gives the material in the classroom, they generally like chatting into one another, or just sitting without doing a scientific and critically thinking. They are really passive on doing so. Hassoubah (2004) states that students can be said less on thinking scientifically because students in doing their activity is less on the process of thinking itself. Therefore, the lecturer must encourage themselves or improve their teaching process for making the students are interested in learning. According to Ardhana (1997) dan Degeng (1999), the less of its optimal in teaching process because (1) lecturers are unable to conduct the learning process which is in line with the development of instructional technology, (2) lecturers have a negative perception or misunderstanding about a learning process, (3) lecturers use learning concept which is not relevant with the development of instructional technology.

Teaching reading comprehension is different with teaching other skill. Teaching reading comprehension can be said complicated because learners have to have other skills, such as; grammar, vocabulary and knowledge. As we know, reading comprehension is derived from two terms, those are reading and comprehension. Reading itself is the process of receiving and interpreting information encoded in language form via the medium of print, Grabe (2009:14). Besides that, reading English texts has importants roles for EFL learners majoring in English since reading is not only as a subject but also as an activity done in studying other English course, Delfi \& Yamat (2017). In fact, learning reading is not learning how to read a text only, but also learning about vocabulary, and grammar. As stated by Hedge (2008) in Delfi \&Yamat (2017) there are general learning goals for the reading component, they are; to adapt reading style according to range of purposes and apply different strategies (skimming and scanning); to build up a knowledge of language (vocabulary and structure) which will facilitate development of greater reading ability. It will build schematic knowledge in order to interpret texts meaningfully; to develop awareness of the structure of written texts in English and 
to be able to make use of rhetorical structure, discourse features, and cohesive devices in comprehending texts, and to take a critical stance to the content of texts. These components are so crucial, if learners do not have these components, of course, they will never be able to comprehend the content of the text. Besides that, in reading activity, the readers have to construct the meaning of words or even sentences which exist as the content of reading text. Meanwhile comprehension occurs when the reader extracts and integrates various information from the text and combines it with what is already known, Koda, (2005:4) in Cahyono and Rohmani, (2012). This comprehension ability is not a passive state which one possesses, but it is an active mental process which needs to be nurtured and improved, Karbalaei \& Rajyashree (2010) in Maybodi \& Maibodi (2017). We typically make use of our background knowledge, vocabulary, grammatical knowledge, experience with the text and other strategies to help us understand the written text. The implementation of strategy here is also important to be used. Therefore, as learners, we have to have an ability and strategy to comprehend the content of a text. So, when we are in the purpose of comprehending the text, we must have a wide range of capacities and abilities. They include cognitive capacities, motivation and various types of knowledge. Here, we should be able to extract the content from any text at all. If we are only able to extract in a single text, of course, it is not satisfying enough. Besides that, comprehension does not occur by simply extracting meaning of from text. Language and content is interrelated to one another. We have to know how language is used for conveying the content. Therefore, we have to read a text carefully, because it relates to our own prior knowledge for interpreting the message that the writer sends to us. It is undeniable that sometimes when some one asks about the content of the passage, we sometimes cannot answer it well. It probably happens because we do not fully comprehend the content of the text. Undeniable, as stated by Nation and Angell (2006) in Maybodi \& Maibodi (2017), the goal of reading is not to read isolated words, but to understand what has been read. For overcoming the problems above, all lecturers are suggested to be more creative in designing and developing their learning process. One of them is through the focal point on R2D2 model.

R2D2 model comes from Recursive, Reflective, Design and Development model. (Colon, Taylor, \& Willis, (2000)). R2D2 is a procedure of constructivist learning design which focuses on its learning process creativity. As the constructivist learning design, this model is different with behaviouristics approach. There are some differences between constructivists and behaviouristics approach. Behaviouristic proponents tend to assume that language is a theory-neutral medium through which meaning about an external world can pass without being influenced or changed, while constructivists tend to believe that meaning of a language develops through use of the language and thus is contextual. Regarding nature of truth, behavioralists proponents think that truth and reality are universal and independent of perception, while the constructivists believe that truth and reality are local and transitory. The behavioralists propose that through the use of proper methods (e.g., scientific research) human can know what that external reality is. They assume that objective knowledge is universal knowledge and that objective can 
be distinguished from subjective. Constructivists deny that objective knowledge exists. They say that humans cannot take a "God's-eye view" and make objective decisions. Positions of the Alternative Model Currently, the majority of the ID models are built upon an objective-rational behavioral theoretical framework. The constructivist approaches to educational technology, however, focus mainly on instructional theory rather than instructional design models. Besides that, this procedure tends to iteratively on its learning and material process. The design is also non-linear, meaning that any aspects of the design which are not fundamentally required to be sequential can be done in any order (Chen \& Toh, 2005), as well as revisited at any time. R2D2 has its characteristics as, 1) The process is recursive, nonlinear, and sometimes chaotic. It depends on real problems on learning which always grows up. (2) Planning is organic, developmental, reflective, and collaborative, (3) Objectives emerge from design and development work. (4) General ID experts do not exist, (5) Instruction emphasizes learning in meaningful contexts, (6) The goal is personal understanding within meaningful contexts, (7) Formative evaluation is critical, and (8) Subjective data may be the most valuable.

Focal point is a structure or procedure model from R2D2 model. It consists of 3 components, they are define, design and development and dissemination. (1) define, it is determining team participatory. It means that the researcher must make a team for supporting what the researcher does. This team can be internal and external learner, learning designer, and subject matter experts. This team is made for creating, supporting, doing solving problems progressively, and developing contextual understanding. This team works from the beginning until the learning process is done. All members have to take part in learning. They have to give in put for making the process of learning process runs smoothly. (2) design and development. This stage is divided into four components, they are (a) determining the place of research, (b) determining media and its format, (c) evaluation procedure, and (4) design and development. And (3) dissemination. In traditional ID process, the subtasks include summative evaluation, final packaging, diffusion, and adoption. With the exception of the summative evaluation, the R2D2 model is similar to the traditional model. The R2D2 model places little emphasis on summative assessment because: 1) the instructional package is only one aspect of successful instruction, 2) it is difficult to generalize from the summative evaluation to other contexts, 3) with different teachers, different students, 4) the manner in which different teachers would use the materials, and 5) a different school and community context may show no guarantee that the material will work the same way in another context.

Based on the explanation above, the researcher formulates the problems as follows:

1. How is student's response during the learning process through focal points on R2D2 model?

2. How is the result of college student's achievement during the learning process through focal points on R2D2 model? 


\section{RESEARCH METHOD}

Based on the focal points on R2D2 model (define, design and development, and dissemination), the researcher arranges the focal points as follows:

\subsection{Definition}

As the first step, the researcher defines a team. It consists of college students, and lecturer from reading comprehension itself. It has a purpose to help and support the researcher during the research being conducted. If there is a problem during the learning process, the team can give some valuable in put for overcoming the problems occur.

\subsection{Design and Development}

This stage is divided into four components, they are: 1) determining the place of research, college students, and lecturer. In this step, the researcher takes STKIP PGRI Pasuruan, Indonesia as the setting of the research, and the subject of the research is college students in academic year of 2015. There are 31 college students, one male and the rest is female. 2) determining media and its format. In this step, the researcher uses picture as media on learning process. 3) designing evaluation procedure. Here, the researcher uses questionnaries to score lecturer' teaching activity during the learning process and gives a test to college students in every meeting. 4) designing and developing. In this case, before the learning process is conducted, the researcher designs and develops the learning through some steps. The steps of desinging and developing the learning are: (a) designing lesson plan and material. Lesson plan and material are developed by the researcher himself based on the syllabus. (b) determining the strategy. The strategy which will be implemented is SQ3R. (c) giving a test. The test is given in every meeting, that is 12 meetings.

\subsection{Dissemination}

After the first and second procedures are gained, then it is disseminated in the classroom in 12 meetings.

\subsection{Technique on Data Analysis}

The data gained from questionnaire and test. The researcher uses descriptive quantitative study on analyzing the data obtained. Before analyzing the data gained, the researcher does some steps below.

Questionarrie. This questionnaire is distributed to college students in every meeting. It is done after the learning process has been done by the lecturer. Here, the college students should give a clue $(\sqrt{ })$ based on the aspects given. The result from questionnaire is analyzed by using the steps which is taken from Muriadi (2013:45), that is 0 (negative response) and 1 (positive response).

The student's learning achievement. The researcher designed and used a scoring rubric. After the researcher got the data, then he calculated the score gained. 


\section{FINDINGS}

After the data obtained, the researcher calculates and counts the result as follows.

\subsection{The student's questionnaire response}

From the total meetings (12 meetings) which are conducted by the researcher, it is found that there are two college students give different score. It can be seen from meeting 1 and 9. In meeting 1, attendance list number 4 gives 'yes' in 13 items from total questions $14(0,93)$. She gives "no" in aspect number 6 . And in meeting 9, attendance list number 23 gives 'yes' in 13 items from total questions $14(0,93)$. But, she gives "no" in aspect number 7.From the calculation which is held by the researcher, it can be said that all students give positive response in all meetings. But, because there ware two students do not attend on learning process, they are number 10 and 28 , so the result does not reach $100 \%$ but $93 \%$ or 0,93 . From this result, it can be said that college students give positive response during the learning process.

\subsection{The result of student's learning achievement}

Table 1.2: Data and analysis data from the result from college student's learning achievement

\begin{tabular}{|c|c|c|c|c|c|c|c|c|c|c|c|c|c|c|}
\hline \multirow{4}{*}{$\begin{array}{l}\text { Number of } \\
\text { attendance } \\
\text { list }\end{array}$} & \multicolumn{12}{|c|}{ Meeting- } & \multirow[b]{4}{*}{ Total } & \multirow[b]{4}{*}{ F.S } \\
\hline & 1 & 2 & 3 & 4 & 5 & 6 & 7 & 8 & 9 & 10 & 11 & 12 & & \\
\hline & \multicolumn{12}{|c|}{ Evaluation score from meeting- } & & \\
\hline & 1 & 2 & 3 & 4 & 5 & 6 & 7 & 8 & 9 & 10 & 11 & 12 & & \\
\hline 1 & 82 & 90 & 93 & 95 & 100 & 83 & 92 & 96 & 90 & 98 & 94 & 98 & 1111 & 93 \\
\hline 2 & 94 & 92 & 93 & 97 & 96 & 86 & 96 & 98 & 90 & 100 & 98 & 98 & 1138 & 95 \\
\hline 3 & 82 & 90 & 94 & 100 & 95 & 90 & 96 & 98 & 90 & 98 & 98 & 96 & 1127 & 94 \\
\hline 4 & 85 & 90 & 94 & 96 & 93 & 86 & 92 & 98 & 90 & 98 & 96 & 98 & 1116 & 93 \\
\hline 5 & 85 & 89 & 93 & 97 & 100 & 86 & 94 & 100 & 90 & 98 & 96 & 96 & 1124 & 94 \\
\hline 6 & 82 & 90 & 93 & 96 & 95 & 83 & 92 & 98 & 90 & 100 & 98 & 94 & 1111 & 93 \\
\hline 7 & 91 & 89 & 94 & 97 & 100 & 86 & 96 & 100 & 90 & 98 & 98 & 98 & 1137 & 95 \\
\hline 8 & 91 & 92 & 96 & 98 & 100 & 86 & 94 & 98 & 90 & 98 & 98 & 92 & 1133 & 94 \\
\hline 9 & 88 & 92 & 94 & 97 & 95 & 86 & 92 & 98 & 90 & 96 & 98 & 94 & 1120 & 93 \\
\hline 10 & - & - & - & - & - & - & - & - & - & - & - & - & - & - \\
\hline 11 & 88 & 89 & 93 & 98 & 96 & 86 & 96 & 98 & 90 & 96 & 96 & 94 & 1120 & 93 \\
\hline 12 & 85 & 89 & 96 & 97 & 100 & 90 & 98 & 98 & 90 & 98 & 98 & 94 & 1133 & 94 \\
\hline 13 & 82 & 89 & 93 & 94 & 92 & 86 & 94 & 96 & 90 & 98 & 98 & 92 & 1104 & 92 \\
\hline 14 & 88 & 94 & 94 & 98 & 96 & 86 & 94 & 98 & 90 & 96 & 98 & 98 & 1130 & 94 \\
\hline 15 & 88 & 89 & 96 & 97 & 100 & 86 & 96 & 98 & 90 & 100 & 98 & 96 & 1134 & 95 \\
\hline 16 & 85 & 92 & 94 & 97 & 95 & 90 & 92 & 96 & 90 & 98 & 96 & 90 & 1115 & 93 \\
\hline 17 & 91 & 90 & 93 & 96 & 95 & 86 & 98 & 98 & 90 & 99 & 98 & 96 & 1130 & 94 \\
\hline 18 & 91 & 89 & 94 & 97 & 96 & 86 & 98 & 98 & 90 & 98 & 98 & 94 & 1129 & 94 \\
\hline 19 & 88 & 92 & 96 & 95 & 96 & 90 & 92 & 98 & 90 & 98 & 94 & 92 & 1121 & 93 \\
\hline 20 & 88 & 92 & 94 & 95 & 96 & 86 & 92 & 96 & 90 & 96 & 98 & 94 & 1117 & 93 \\
\hline 21 & 85 & 89 & 93 & 96 & 95 & 90 & 98 & 98 & 90 & 96 & 98 & 91 & 1119 & 93 \\
\hline 22 & 85 & 90 & 92 & 97 & 93 & 90 & 94 & 100 & 90 & 100 & 98 & 94 & 1123 & 94 \\
\hline 23 & 85 & 94 & 93 & 97 & 95 & 90 & 98 & 98 & 90 & 100 & 98 & 96 & 1134 & 95 \\
\hline 24 & 82 & 89 & 94 & 100 & 95 & 90 & 94 & 96 & 90 & 100 & 98 & 98 & 1126 & 94 \\
\hline 25 & 88 & 89 & 96 & 100 & 93 & 90 & 90 & 98 & 90 & 98 & 98 & 96 & 1126 & 94 \\
\hline 26 & 94 & 96 & 93 & 100 & 95 & 90 & 94 & 96 & 90 & 100 & 98 & 98 & 1144 & 95 \\
\hline 27 & 82 & 89 & 92 & 95 & 91 & 86 & 94 & 98 & 90 & 98 & 92 & 94 & 1101 & 92 \\
\hline 28 & - & - & - & - & - & - & - & - & - & - & - & - & - & - \\
\hline
\end{tabular}




\begin{tabular}{|l|l|l|l|l|l|l|l|l|l|l|l|l|l|l|}
\hline 29 & 82 & 90 & 96 & 95 & 91 & 90 & 94 & 98 & 90 & 98 & 96 & 94 & 1114 & 93 \\
\hline 30 & 85 & 89 & 92 & 94 & 93 & 90 & 98 & 96 & 90 & 98 & 98 & 96 & 1119 & 93 \\
\hline 31 & 86 & 89 & 93 & 95 & 93 & 86 & 96 & 96 & 90 & 100 & 98 & 96 & 1118 & 93 \\
\hline
\end{tabular}

From the table above, it can be seen that in the first meeting there are 7 college students get 82, and others get more. After all scores are calculated from first until last test, it can be said that all students are success on doing a test given and can be said master. It is because the result or the score is $\geq 80 \%$ from total college students who get more than 90. And it is an excellent score.

\section{DISCUSSION}

For getting a good appreciation and learning achievement, teaching and learning process should be implemented well in the classroom. This implementation can be said well if lecturer and college students collaborate into one another. This happens if lecturer and college students know their own existence. It means, the lecturer must prepare his learning tools, such as lesson plan, material, media, and its strategy and college students should participate and take part in learning process. Discussing about strategy, based on the result of research (Dole, Brown, \& Trathen, 1996; Janzen,2003; Karbalaei \&Rajyashree, 2010; Khoshsima \& Rezaeian, 2014; Pakzadian \& Eslami Rasekh, 2012; Nurhayati, 2014; Roohani, et al., 2015; Deshpande, 2016; Teng, 2016; Damayanti, 2017) in Maybodi \& Maibodi (2017) states that together with direct instructions when students are taught reading strategies this will improve not only their comprehension of the reading passage but also their performance on the tests. Moreover, here for arousing students' participation, the lecturer must give a motivation and a broad chance to college students to construct their own learning. However, the simple and easy word motivation might appear in its face difficult to define, Abisamra (2012) in Nemati (2016). Besides that, the lecturer must use a proper strategy on his learning. In other words, lecturer and college students must collaborate in learning process for avoiding boredom. As stated by Mustadji, (2009) in Suparno,(1999), and in Nur, (1998) constructivist approach sees that students individually and or collaboratively construct their own knowledge. In other words, the core of constructivism is authentic learning, Ozturk and Cecen (2007) in Nemati (2016). But, if the lecturer and college students do not know their position, the learning process cannot run well. According to Ardhana (1997) and Degeng (1999), the less of its optimal in teaching process because (1) lecturers are unable to conduct the learning process which is in line with the development of instructional technology, (2) lecturers have a negative perception or misunderstanding about a learning process, (3) lecturers use learning concept which is not relevant with the development of instructional technology. Meanwhile, for making college learners have a lot of experience on comprehending a text, vocabulary, and grammar or structure, the Lecturers can give them a task. It is in line with Martini (2008) in Delfi and Yamat (2017) whereas she gives suggestions toward the teacher or lecturer for giving motivation to students to read a lot of reading material, be creative in finding interesting reading material, be a good model, giving a lot of reading tasks which can be read at home, and control the students' reading activities outside of the classroom by using written report. 


\section{CONCLUSION}

From the result of the questionnaire and test which were already obtained and calculated by researcher from 12 meeting, it shows that the learning process through focal points on R2D2 has positive response. It can be seen from the result of questionnaire given, that is $93 \%$. Besides that, the result of student's learning achievement show success. It is because the result of calculation from first score until last score, all students get more than 90. It indicates that the learning process through focal points on R2D2 model can be implemented by all lecturers on learning process.

It is suggested to other researchers to do a similar research in different subjects to make this research objectively can be proven. Besides that, hopefully, other researchers can broadly design and develop other strategy which can enrich our knowledge in developing strategy for making the learning process especially students or college students to interest and enjoy the material given in the classroom.

\section{REFERENCES}

Ardhana,W. (1997). Pandangan Konstruktivistik Tentang Pemecahan Masalah Belajar. Makalah Seminar TEP PPS IKIP Malang.

Cahyono, B.Y. \& Indah, R.N. (2012). Second Language Research and Pedagogy. Toward the Development of English Language Teaching in Indonesia, State University Malang Press.

Chen, C. J., \& Toh, S. C. (2005). A feasible constructivist instructional development model forvirtual reality (VR)-based learning environments: Its efficacy in the novice car driver instruction of Malaysia. In ETR\&D 53(1) pp. 111-123. Retrieved March 18, 2007 from Ebsco Host online database

Colon, B., Taylor, K. A., \& Willis, J. (2000). Constructivist instructional design: Creating a multimedia package for teaching critical qualitative research. Retrieved March 27, 2007 from http://www.nova.edu/ssss/QR/QR51/colon.html

Degeng, N.S. (1999). Mencari Pendekatan Baru Pememcahan Masalah Belajar, Jayapura: Yayasan Jayawijaya, Kuala Kencana PT.Freeport Indonesia.

Degeng, N.S. (2013). Ilmu Pembelajaran: Klasifikasi Variabel untuk Pengembangan Teori dan Penelitian, Aras Media, Bandung.

Delfi, Syofia \& Yamat, Hamidah. (2017). Extensive Reading in Developing English Competency for Indonesian EFL Learners Majoring in English. IJELTAL (Indonesian Journal of English Language Teaching and Applied Linguistics), 1(2), 2017.

Grabe,W. (2009). Reading in A Second Language Moving from Theory to Practice, Cambridge, University Press.

Hassoubah, Z. (2004). Developing Creative and Critical Thinking Skills (terjemahan), Bandung; Yayasan Nuansa Cendia.

Maybodi, A. S. P. \& Maibodi, A.H. (2017). The Effect of Teaching Summarization Strategies on Reading Comprehension of Science and Humanities Iranian High School Students. Indonesian Journal of EFL and Linguistics, 2(1), 2017 
Mustaji. (2009). Pengembangan Model Pembelajaran Berbasis Malah Dengan Pola Kolaborasi Dalam Mata Kuliah Masalah Sosial, ProgramStudi Pascasarjana, Universitas Negeri Malang

Muriadi. (2013). Pengembangan Perangkat Pembelajaran Matematika Tipe Problem Posing untuk Meningkatkan Penguasaan Konsep Operasi Bentuk Aljabar. Tesis tidak diterbitkan. Malang: PPs UM.

Nemati, Azadeh. (2016). Portfolio Keeping Ends to a Good Product: The Cases of Reading and Motivation. ASIAN TEFL, 1(2), 2016

Willis, J. \& Wright, K.E. (2000). A General Set of Procedure for C-ID: the New R2D2 model. Educational Technology, Mar-Apr.5-20 